\title{
O JOGO DA LEITURA: O BANQUETE DE PLATaO*
}

\author{
Celina Moreira de Mello
}

Universidade Federal do Rio de Janeiro

\section{RESUMO}

O filósofo da República é convocado enquanto repre sentante da Poesia ou República das Letras. O que se deu como lógos se interpreta enquanto mito, resuitado de um discurso, a Psicanálise, em demanda de Ciência, Lógos, empurrando, de certa forma, os outros discursos - tal a Filosofia - para o lugar do Mito.

\section{Introduçāo ou da ironia}

O filósofo da República é aqui convocado enquanto representante da Poesia ou República das Letras. O que se deu como Logos se interpreta enquanto Mythos, resultado de um Discurso, a Psicanálise, em demanda de Ciência, Logos, empurrando de certa forma os outros discursos - tal a Filosofia - para o lugar do Mito.

\section{Prólogo}

Quem é Platão? O que é o Banquete? Quem são os convidados deste Banquete? A História responde: Platão pertencia a uma das mais ilustres familias atenienses. Muito jovem ainda, seduzido pela dialética socrática, seguirá, entre 407 e 399 , as aulas deste popular mestre. Após a morte de Sócrates, faz uma longa viagem, que poderíamos chamar de estudos no exilio, e de volta a Atenas compõe seus primeiros diálogos entre os quais a Apologia de Sócrates, o Protágoras e Górgias. Parte, então, para a Itália meridional, interessado pelas doutrinas pitagóricas e órficas, e após uma série de aventuras político-amorosas, em Siracusa, volta a Atenas,

- Comunlcą̧̆o apresentada na mesa-redonda "O Tempo de Concjuir - O Banquete o Amor" na Casa de Cultura Laura Alvim a 16 de dezembro de 1997. 
fundando em 387, nos jardins chamados Academos, uma escola de filosofia que será chamada Academia. Durante quarentá anos será o mestre de uma geração de matemáticos e filósofos, dentre os quais o mais conhecido é, sem dúvida, Aristóteles. Fédon, o Banquete, Fedro e a República são os diálogos que escreveu nesta época. O final de sua carreira é marcado por novas viagens no intervalo das quais escreve seus últimos diálogos. ${ }^{1}$

O Banquete não pode ser dissociado de Fédon embora não se possa dizer qual a ordem de composição destes dois diálogos, nem afirmar com toda certeza a sua data de com. posição. A data aproximada seria por volta de 385 , tomandose como ponto de referência a alusão a determinados acontecimentos históricos: o termo usado por Aristófanes, quan. do conta a separação que os seres humanos sofreram de si próprios, é "dioecismo". "Dioecismo" é o termo que indica o castigo imposto por um Estado a uma cidade vassala que se revoltasse, sua unidade social era rompida dispersando-se os habitantes por grupos isolados. Ora, Xenofonte relata que Esparta impusera tal castigo a Mantineia cujos habitantes foram dispersos em cinco aldeias, para puni-la de suas traições durante a guerra do Peloponeso, em 385, trinta e um anos depois do banquete que é narrado no diálogo e tal anacronismo se explicaria por este acontecimento ainda recente para a memória dos atenienses. Mas há outras teorias e até outras datas. ${ }^{2}$

Os convidados deste Banquete sāo personagens da crônica politica e artistica de Atenas, como Alcibíades e Aristófanes, outros são personagens cujos nomes chegaram até nós através dos diálogos de Platão, como Fedro. E, finalmente, há Sócrates que todos nós pensamos conhecer. Resta a questão do diálogo.

\section{A fraude}

O leitor-crítico, e aqui estou esta noite convocada enquanto leitor-crítico, dentro das perspectivas que a interpretação do texto literário descortina, define Platão como a instância que assina o texto que se quer, em seu projeto primeiro, como recusa da escritura, ou seja, mera escrita ou transcrição de um diálogo. Platão assina a fraude que consiste em apresentar um texto como rastro fiel de vozes que um dia ressoaram e dialogaram num determinado espaço e, neste

1 Cf. DUMONT. J.P. La philosophie antique. Paris. PUF, 198B. p. $39-11$.

2 Cf. Platon, Oouvres compldtes. Parls. Les Belles Lettres, 1976. v. 4, p. viij-ix. 
jogo de revela-não-esconde em que esconde que escreve, nos oferece este Banquete como se ouvissemos a gravação (distorcida embora pela narrativa em segunda mão de um relato gerado pelo esquecimento) das amenas trocas de gracejos entre comensais de um vago jantar de intelectuais ou membros da Ordem dos Companheiros do Bom Copo. O que não deixa de lembrar o insano labor que consiste em apagar $e$ transcrever discursos de politicos na Câmara e no Senado, estabelecer a versāo autorizada dos Seminários de Lacan, ou pensar que gravações reproduzem numa dimensão acústica uma possivel verdade. $O$ que se escreveu como LOGOS, palavra da reflexāo, acabou se dando como MYTHOS, palavra da ficção, numa volta à antiga sinonimia pré-socrática que uma cadeia de filósofos havia tentado separar.

Platão é aqui nada mais do que uma assinatura. O Banquete $e$, então, um texto e como todo texto carreia um infinito paradigma de possiveis leituras que põem em funcionamento sua máquina produtora de sentidos e não a voz do oráculo Sócrates. Este, por sua vez, é juntamente com os outros comensais, apenas um dos convidados deste Banquete, o mais importante. Nāo porque a História diga que foi o mais importante, mas simplesmente pelo suspense que antecede sua chegada, pelo lugar de honra que lhe é reservado, à direita do anfitriäo, Agáton, porque é o último a falar e seu discurso ocupa mais páginas do que o dos outros personagens deste texto. Pois é isto que é Sócrates - no Banquete (não sei como foi ou como seria, ali ou em outros textos): um personagem de um texto assinado por Platão.

Condenada pela minha ignorância do grego a ler uma traduçāo e na impossibilidade de avaliar por mim mesma a beleza da textura do texto, vejo-me obrigada a falar da sua estrutura. Que me aparece como sendo dupla e que tentarei expressar por meio de metáforas.

A primeira, a mais evidente e irresistivel para a leitora perversa que sou, consiste em ver o texto se estruturando como um Banquete.

Cabe, aqui, uma reflexão sobre o título deste diálogo. Em grego To symposion que a tradição latina traduz como Convivium. Um symposion compunha-se de duas partes: a primeira, sem importância, era a refeição propriamente dita, c deipnon ou syndeipnon e a segunda, potos ou sympotos em que os convidados bebem juntos e tornam-se sympotoi, ou seja, co-bebedores, que discursarāo sobre um assunto previamente escolhido. O jantar é, portanto, apenas um prólogo do que virá a seguir, o sympotos, que é preparado por libaçōes, preces e cantos que lhe conferem um caráter quase 
sacro. ${ }^{3}$ Os convidados decidem, então, como deverão beber e qual $o$ assunto que será discutido enquanto bebem. Um presidente - aqui, Fedro - será responsável pela execução do programa. Todos os oradores se dirigirão, pois, a Fedro, exceto ele próprio e Alcibiades, cuja entrada constitui uma ruptura da ordem deste symposion que degenera em orgia.

Os discursos representam uma competição, uma espécie de concurso de oratória e, no Banquete, estruturam-se como um syssities ou banquete, refeição formal, solene, em que são servidos muitos pratos apresentados ao apetite e à apreciação dos comensais, numa sucessão que segue uma ordem de importância e requintes crescentes, num "crescendo". Um pouco de certa maneira, como aqui, em que a Literatura aparece como o aperitivo da Psicanálise ou o que a Psicanálise pretende devorar, pois já dizia a Esfinge "Decifra-me ou te devoro". Assim, os discursos de cada convidado sobre o deus Eros organizam-se de tal modo que, seguindo a ordem para a direita, "ouvimos" primeiro o menos interessante e assim sucessivamente até o prato principal, esperado com ansiedade por todos os presentes, aquele que deseja sua gula nāo tāo secreta: o que Sócrates terá a dizer sobre o amor?

Mas antes ouvimos Fedro, Pausânias, Erixímaco, Aristófanes e Agáton. Cinco discursos de conteúdos e estilos variados, num belo exercício literário que multiplica por cinco o encômion: primitivamente um canto executado num banquete, que se transforma em discurso de louvor com regras de composição bem precisas, definidas no Banquete por Agáton. Cinco discursos, pois, apresentando doutrinas às vezes opostas, às vezes complementares, que serão todas refutadas por Sócrates, cujo discurso retoma afirmações anteriores com as quais argumenta. Fedro, Pausânias e Erixímaco narram, de início, a origem do deus do Amor, Eros, recorrendo à mitologia e à tradição religiosa helênicas. Fedro exalta o Amor, evocando três amantes da tradição mitológica: Alceste, Aquiles, Orfeu. Pausânias, de certa maneira, passa da mitologia à sociologia, justificando pela dupla filiaçāo que a tradição atribui a Eros, os dois tipos de amor presentes na sociedade grega: o amor pela mulher, modalidade inferior, inspirada pela beleza do corpo, e o amor pelos jovens, modalidade superior, inspirada pela beleza da alma. O discurso de Pausânias, na verdade, constitui uma defesa apaixonada do homossexualismo, costume mais ou menos aceito na Grécia. Erixímaco segue a mesma linha de argu-

3 PLATON, p. xili. Os latinos, entretanto, traduzem syndeipnen e symposium por compolatio ou concenation. mostrando desta forma quo a diferenca cntre cstes dots momentos se perdera com o tempa. 
mentação, mas exalta as propriedade médicas do amor, fazendo deste um fenômeno físico.

Aristófanes faz o mais belo discurso, apresentando, com originalidade, o mito do andrógino e louvando, o único dos convivas, o amor nas suas finalidades: o amor heterossexual, que reproduz a espécie, e o amor homossexual, que alivia as tensões dos humanos. Após o autor cômico, fala o autor de tragédias Agáton, cujo discurso é uma bela peça de retórica, criticada pela tradição filosófica por ser um discurso vazio. Esta é primeira parte do Banquete.

A segunda apresenta o discurso de Sócrates. Aqui, tornase evidente a segunda estruturação do conto que chamarei de "bonecas russas". O cerne do Banquete, seu discurso mais importante é o de Sócrates, que contém a narração do que the dissera, um dia, sobre o deus do Amor, uma sacerdotisa de Mantinéia, Diotima. O discurso de Sócrates, por sua vez, integra a narração que o Apolodoro faz, a um amigo, deste cymposion. Fatos que conhece graças à narração de Aristodemos que se encontrava presente a este symposium. Temos, então, o seguinte encadeamento: Platão conta que Aristodemo contou a Apolodoro que conta a um amigo o banquete em que Sócrates conta o que lhe contou Diotima.

Mas a "bonequinha" menor, aquela que se encontra na narração đe Diotima, é o próprio Sócrates. A sacerdotisa de Mantinéia, para justificar sua afirmação de que o amor não é nem belo, nem feio, nem bom, nem mau, nem uma divindade, nem um homem, conta o mito de seu nascimento e faz do Amor um demônio - ser intermediário entre os deuses e os homens - filho de Pénia, a Pobreza e do Póros, o Expediente, filho de Métis, a Invenção. Mas a descrição que Diotima faz do Amor parece, curiosamente, com uma descrição do próprio Sócrates, ressaltando sua dualidade: ambos são rudes, sujos, descalços, sem abrigo, vivendo na indigência, como Pénia e virís, corajosos, engenhosos, filósofos, feiticeiros, mágicos e sofistas, qualidades que viriam de Póros.

Tal dualidade de Sócrates é o mote do discurso de Alcibiades que constitui a terceira parte do Banquete. A chegada de Alcibíades, bêbado, em companhia de um grupo de "companheiros de alegria", rompe com a organização do potos. Ele deita-se ao lado de Agáton e Sócrates mas alega não poder elogiar ninguém - nem mesmo o Amor - na presença do filósofo que o constrange. Erixímaco propōe-lhe, entāo, que faça o encômion de Sócrates. Alcibíades falará, de início, por meio de imagens: Sócrates é, por ele, comparado aos Silenos, espécies de Sátiros, feíssimos, que geralmente enfeitavam armários. Estes, em seu interior guardavam, entretanto, ob- 
jetos belos e preciosos. Sócrates é como um feio Sileno, "seu exterior dá a impressão de se estar em presença de um ignorantāo, de um tolo" 4 mas se for aberto, veremos que contem muita sabedoria. Esta imagem funciona como uma representação, não somente do filósofo, mas da estrutura deste diálogo, tão diferente dos outros. Seu envelope, este symposium, envolve e contém, se pudermos abri-lo, um diálogo, tão diferente dos outros. Seu envelope, este symposium, envolve e contém, se pudermos abri-lo, um diálogo entre a Filosofia e a Retórica, o LOGOS e o MITO, e também, um diálogo entre Platão e Aristófanes, ou melhor, a resposta de Platão às Nuvens, comédia em que aquele autor fizera uma cruel caricatura de Sócrates. O Aristófanes do Banquete, tornando-se por sua vez personagem de Platão, é apresentado como sempre ocupado por Dionísios e Afrodite ou seja como um bom copo e um farrista; não pode falar porque, de tanto beber, está com soluços - artifício que aproxima o discurso de Aristófanes do discurso de Agáton, a fala da Comédia antecedendo a fala da Tragédia -; e a "bonequinha menor" do Banquete, a descrição que Diotima faz do Amor e que é a de Sócrates ("é preciso que o Amor seja filosófico"s) retoma a caricatura de Sócrates apresentada nas Nuvens por Aristófanes.

Mas por que não falar da concepção de Amor tal como é apresentada por Sócrates, ou seja a Filosofia, neste Banquete? Afinal, trata-se de um invólucro que contém muita sabedoria: e apresenta, de modo magnífico, tal como analisa Lacan em seu Seminário Sur le Transfert, os limites do método socrático. Para nós, convivas de uma outra época e de uma outra cultura, o lugar que a mulher, aparentemente, ocupa no symposium, é estranhamente insignificante: näo há mulheres neste banquete a não ser a tocadora de flauta que é mandada embora antes dos discursos. Na teoria sobre o Amor, os discursos, Fedro fala do amor de Alceste por seu marido Admeto, mas dá maior valor a Aquiles, amado de Pátroclo; Aristófanes valoriza o amor heterossexual que reproduz a espécie enquanto que o amor homossexual - entre homens - só produz políticos, espécie que parece não apreciar, e Diotima considera que o Amor caracteriza-se, qualquer que seja, do corpo, da alma, pelas mulheres, pelos belos jovens, por um desejo de imortalidade que leva à criaçãoreprodução. E o resto é uma longa e constante apologia do "amor grego". Na prática do amor, neste contexto, que apre-

4 Platxo. Diálogos l: Mẻnon. Banquete, Fedro. Rio de Janelro. Ed.Ouro. 1966. D.1B1.

5 PLATXO. D.203. 
senta vários casais, só há homens apaixonados por belos jovens.

Por que é uma mulher quem faz o uiltimo discurso sobre - Amor? Por que Sócrates passa a palavra para Diotima? Lacan repete, com insistência, esta pergunta no seu Seminário Sur le Transfert.

Há, neste Seminário, várias respostas.

A primeira é que, na Grécia, apesar do costume do "amor grego", a mulher tem seu lugar e exige o que the é devido. nele.

A segunda é que Sócrates deixa falar a mulher que há

A terceira é que o método socrático teria seu limite na possibilidade de falar do amor, que só a dialética não poderia falar de algo que não é nem belo nem feio, nem deus nem homem; este seria objeto não da sabedoria (sofia) nem da ignorância, mas da opinião, ou doxa.

Diz, então, Lacan que a ciência é obrigada a deixar a palavra àquela que expressa o mito, ilustrando perfeitamente a oposiçāo que há entre o discurso de Agáton - "quem não sabe fala" - e o discurso de Sócrates - "quem sabe não fala".

Diria Camus que onde a ciência pára, começa a metáfora. Onde o Diálogo é impróprio, aparece o mito.

Onde a Psicanálise falha, a Literatura fala?

Qualquer que seja a resposta, a mulher excluida do Ban. quete mas que se procura em cada prato vazio é o recheio que Sócrates vai oferecer aos comensais.

\section{Conclusão}

Por que não analisar, então, as teorias sofísticas e filosóficas do Banquete?

O próprio Sócrates esvazia qualquer tentativa neste sentido, quando é convidado por Agáton a deitar-se a seu lado:

ótimo seria, caro Agáton, se a sabedoria fosse uma cousa que pudesse passar, por simples contato, de quem a tem a quem não a tem, assim como a água que por um fio de lã corre de um cálice cheio para um cálice vazio. Se tal valesse igualmente para a sabedoria, eu não saberia dizer o quanto me regozija deitar-me ao teu lado, pois assim me encheria de tua bela sabedoria. Eu, o que sei é inferior e duvidoso, percebido como que através de um sonho; tua sabedoria, porém, é esplêndida e continua 
a crescer: fulgurou em ti, jovem ainda, e resplandeceu há pouco como brilhante luz perante trinta mil espectadores gregos! ${ }^{\circ}$

Esta sabedoria, a supor que eu a tivesse, não poderia ser desta forma transmitida.

Para concluir, volto-me, pois, mais uma vez à estrutura clas bonequinhas russas. Vimos que a menor de todas é o próprio Sócrates que empresta suas características ao de. mônio do amor, e que, neste texto, retoma Platão a caricatura feita por Aristófanes nas Nuvens. $O$ cerne do texto, seu prato principal é, pois, nada menos, na terminologia platônica, do que um reflexo de um reflexo - entre os dois espelhos, o de Platão refletindo o de Aristófanes, a própria tessitura dos textos, a ausência de Sócrates - o prato principal deste Banquete é, pois, um prato vazio.

\section{REFERENCIAS BIBLIOGRAFICAS}

1 DUMONT, J. P. La philosophie antique. Paris, PUF, 1968.

2 LACAN, J. Sur le transfert. Seminário de 60-61. Mimeografado.

3 PLATAAO. Diálogos I: Mênon, Banquete, Fedro. Rio de Janeiro, Ed. Ouro, 1966.

$4 \longrightarrow$ Oeuvres complètes. Paris, Les Belles Lettres, 1976. 